\begin{tabular}{|c|c|c|}
\hline SilRT & $\begin{array}{c}\text { Türkiye Tarımsal Araştırmalar Dergisi } \\
\text { dergipark.org.tr/tutad }\end{array}$ & $\begin{array}{l}\text { Turk J Agric Res } \\
\text { 2020, 7(3): 321-326 } \\
\text { ○) TÜTAD } \\
\text { ISSN: 2148-2306 }\end{array}$ \\
\hline 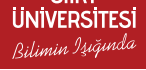 & Araştırma Makalesi / Research Article & $\begin{array}{l}\text { e-ISSN: } 2528-858 X \\
\text { doi: 10.19159/tutad.773412 }\end{array}$ \\
\hline
\end{tabular}

\title{
Türkiye’deki Tiftik Üretimi Değişiminin Regresyon Analizi ile İncelenmesi
}

\author{
Adile TATLIYER* \\ Kahramanmaraş Sütçü İmam Üniversitesi, Ziraat Fakültesi, Zootekni Bölümü, Kahramanmaraş, TÜRKİYE
}

\begin{tabular}{ll}
\hline \multicolumn{1}{c}{ Geliş Tarihi/Received: 24.07 .2020} & Kabul Tarihi/Accepted: 06.11 .2020 \\
\hline ORCID ID & \\
\hline (D) orcid.org/0000-0002-4239-7072 \\
*Sorumlu Yazar/Corresponding Author: atatliyer@ksu.edu.tr
\end{tabular}

Öz: Bu çalışmanın amacı, Orta Asya'dan günümüze kadar gelen ve Türkiye'nin önemli gen kaynaklarından biri olan Ankara keçisinin ve Ankara keçisinden elde edilebilen tiftiğin miktarının, Türkiye'de 1991-2019 yılları arasında gerçekleşen değişimleri farklı regresyon modelleri ile incelemek ve sonuçları değerlendirmektir. Bu amaçla çalışmada, basit doğrusal, karesel, kübik, ters ve logaritmik regresyon modelleri kullanılmıştır. Regresyon modellerinin karşılaştırması ve en uygun modelin belirlenmesi amacıyla karşılaştırma kriteri olarak hata kareler ortalamasının karekökü (Root Mean Square Error, RMSE) ile belirleme katsayısı $\left(R^{2}\right)$ ve düzeltilmiş belirleme katsayıs1 $\left(A d j R^{2}\right)$ kullanılmıştır. Buna göre, kırkılan Ankara keçisi için, basit doğrusal, karesel, kübik, ters ve logaritmik regresyon modellerinden elde edilen $R^{2}$ değerleri sırasıyla $0.64,0.99$, $0.99,0.74,0.90$ ve RMSE ise sirasıyla 135288.27, 25651.46, 18966.20, 114681.75, 71592.54 olarak belirlenmiștir. Tiftik üretimi için aynı sıra ile $R^{2}$ değerleri $0.61,0.98,0.99,0.75,0.88$ iken, RMSE ise sırasıyla 208.99, 41.84, 32.64, 167.85 ve 114.32 'dir. Ankara keçisi sayısında ise $R^{2}$ değerleri 0.70, 0.99, 0.99, 0.73, 0.93 iken, RMSE ise sırasıyla 165264.22, 32818.49, 23410.64, 155421.63 ve 79544.79'dur. Parametre tahminlerinde, en yüksek $R^{2}$ değeri ve en düşük RMSE değerine göre en uygun model Kübik regresyon modeldir. Kübik regresyon modeline göre Türkiye'de 2020 ile 2021 yıllarında kırkılacak Ankara keçisi sayısının sırasıyla 254307 baş ve 275431 baş, Ankara (tiftik) keçisi sayısının 268321 baş ve 287846 baş ve Türkiye tiftik üretiminin ise 439 ton ve 474 ton olacağı tahmin edilmiştir. Gelecek y1llarda Türkiye'de tiftik üretiminde bir artış görülse de bu durum beklenenin çok altındadır.

Anahtar Kelimeler: Tiftik, Ankara keçisi, karesel regresyon, kübik regresyon, ters regresyon, logaritmik regresyon

\section{Investigation of the Changes of the Mohair Production in Turkey with Regression Analysis}

\begin{abstract}
The aim of this study is to investigate the changes in the number of Angora goat and the amount of mohair obtained from Angora goats, which is one of the Turkey's important gene sources from Central Asia to present day, between 1991-2019 in Turkey via different regression models and to evaluate the results. For this purpose, simple linear, quadratic, cubic, inverse, and logarithmic regression models are used in the study. In order to compare the regression models and determine the most suitable model, the square root of the mean squares (Root Mean Square error-RMSE), the determination coefficient $\left(R^{2}\right)$ and the adjusted determination coefficient $\left(A d j R^{2}\right)$ were used as comparison criteria. Accordingly, $R^{2}$ values obtained from simple linear, quadratic, cubic, inverse and logarithmic regression models for the number of Ankara goats shorn are $0.628,0.99,0.99$, $0.74,0.90$, and RMSE are 135288.27, 25651.46, 18966.20, 114681.75, 71592.54, respectively. For Mohair production, $R^{2}$ values are $0.61,0.98,0.99,0.75,0.88$, while RMSE is $208.99,41.84,32.64,167.85$ and 114.32 respectively. In the number of angora goats, $R^{2}$ values are $0.70,0.99,0.99,0.73,0.93$, while RMSE is $165264.22,32818.49,23410.64,155421.63$ and 79544.79, respectively. In parameter estimates, the most appropriate model according to the highest $R^{2}$ value and the lowest RMSE value is the cubic regression model. According to the cubic regression model, the estimated number of Angora goats that will be shorn, the number of Angora (mohair) goat, and mohair production in Turkey will be 254307 and 275431 heads, 268321 and 287846 heads, and 439 and 474 tons in 2020 and 2021, respectively. Although in the coming years, an increase in mohair production is projected in Turkey, this is much lower than expected.
\end{abstract}

Keywords: Mohair, Angora goats, quadratic regression, cubic regression, inverse regression, logarithmic regression 


\section{Giriş}

Biyolojik olarak değerli bir hayvansal ürün olan hayvansal liflerde, hayvanların derisinde bulunan özel foliküller tarafından üretilen keratin bazlı proteinler bulunmaktadır. Hayvansal liflerin fiziksel özellikleri kullanım alanlarını şekillendirmektedir. Örneğin küçük lifin çapı, yüksek kalitedeki dokuma giysilerinde; büyük çaplı lifler ise daha kalın giysilerde, zemin döşemelerde ev tekstilinde kullanılmaktadır. Biyolojik olarak değerli olan hayvansal lifler, kullanım alanı bakımından da ekonomik bir öneme sahiptir. Hayvansal lifler içinde Ankara genotipi (Capra hircus angorensis), hayvansal lif üretiminde önemli bir yere sahiptir (Galbraith, 2010).

Doğal hayvansal liflerden olan tiftik, Türkiye'nin önemli gen kaynaklarından biri olan Ankara keçisinden elde edilmektedir. Türklerin Orta Asya'dan Anadolu'ya göç etmesiyle Türkiye'de yerleştiğine inanılan tiftik keçisi, bozkır iklimin hâkim olduğu Ankara'da daha çok yetiştirildiği için, uluslararası platformda "Ankara keçisi” olarak tanınmaktadır. Bu bakımdan, tiftik kültürel bir miras niteliğindedir.

Türkiye'de özellikle İç Anadolu Bölgesi'nde (Ankara, Çankırı, Eskişehir, Konya, Niğde, Kırşehir, Nevşehir, Sivas ve Yozgat), Ege Bölgesi'nde (Kütahya ve Afyon), Marmara Bölgesi'nde (Bilecik) ve Karadeniz Bölgesi'nde (Kastamonu, Zonguldak, Bolu ve Çorum) yoğunlukla yetiştirilen Ankara keçisi; Doğu Anadolu Bölgesi'nde (Erzurum, Bingöl, Bitlis ve Van) ve Güneydoğu Anadolu Bölgesi'nde (Siirt ve Mardin illerinde) de yetiştirilmektedir (Özdemir, 2009). Türkiye'de Ankara keçilerinin k1l örtüsü 'tiftik' olarak adlandırılmakta iken, Arapça'da mohair (mukhayyar) olarak adlandırılmaktadır. Ankara keçisi, et ve süt üretiminden ziyade tiftik üretimi için yetiştirilmektedir. Genellikle beyaz renkte olan Ankara keçisi, kahverengi, siyah, sarı, gri ve krem renklerde de olabilmektedir (Kantürk Yiğit, 2011).

On sekizinci yüzyıla kadar Türkiye'nin tekelinde olan Ankara keçisi ve tiftik üretimi, 1838 yılında Güney Afrika Cumhuriyeti'ne ve ardından 1846 yılında Ankara keçilerinin Amerika Birleşik Devletleri'ne götürülmesinden sonra Türkiye tiftik tekelini elinden kaybetmiştir (Kaymakçı, 2006).

Kumaş dokuma sektöründe hammadde olarak kullanılan tiftik; soğuktan koruyan, 1lık havalarda vücut 1sısının atılmasını sağlayan önemli bir moda elyafıdır. Aynı zamanda yanmaya dayanıklı olmasiyla da ev dekorasyonunda kullanılabilmektedir. Tiftik bu üstün niteliklerinden dolayı, hayvan ıslahında seleksiyon çalışmalarında üzerinde durulan ekonomik öneme sahip bir özelliktir.

Ankara (Tiftik) keçisinin Anadolu'daki geçmişi çok eskilere dayanmasına rağmen son yıllarda, çeşitli sektörlerde bitkisel bazlı yapay sentetiklerin daha çok tercih edildiğinden, diğer hayvansal liflerde olduğu gibi tiftik kullanımı da giderek azalmıştır. Daşkıran ve ark. (2010), politik ve sosyal-ekonomik nedenlerden dolayı, Türkiye'de tiftik üretimi, et üretimi ve süt üretiminin çok gerisinde kaldığını bildirmişlerdir. Özellikle ekonomik gelirini tiftikten sağlayan kırsal kesimde bu azalışın etkisi daha keskin bir şekilde görülmüştür.

Çeşitli tarımsal ürünlerinin değişiminin istatistiksel analizlerinde zaman serileri analiz yöntemlerinden faydalanılarak yapılan çalışmalar mevcuttur (Çelik, 2015; Bağcıtek, 2017). Gujarati ve Porter (2008), zaman serileri analizi için veri seti uzunluğunun en az 40 olmasının sağlıklı sonuç için gerekli olduğunu bildirmişlerdir. Veri seti uzunluğunun yeterli olmadiğ 1 durumlarda, farklı regresyon modelleri kullanılarak (MARS, linear, kübik, ters, logaritmik regresyon) yapılan pek çok çalışma bulunmaktadır (Çelik ve ark., 2018a ve 2018b; Tahtalı ve Yıldızbaş, 2020). Tahtalı ve Yıldızbaş (2020), Romanov kuzuları üzerinde yaptıkları çalışmada, en yüksek $R^{2}$ değerini kübik modelden elde etmişlerdir. Akbaș ve ark. (1999), Dağlıç ve Kıvırcık kuzularında büyüme performanslarını karşılaştırmak için çeşitli regresyon modelleri kullanmıştır. Araştırıcılar, performans karşılaştırmalarında en iyi modelin Dağlıçlarda basit doğrusal modelin Kıvırcıklarda ise kuadratik model olduğunu bildirmişlerdir. Bununla birlikte regresyon modellerinin kullanıldığ 1 farklı türler üzerinde yapılan pek çok çalışma literatürde mevcuttur (Banerjee, 2011; Zimmermann ve ark., 2019).

Tiftik keçisinin ticari, coğrafi, zirai ve tarihî yönlerinin önemini vurgulayan Sanal ve ark. (2019), yaptıkları çalışmada Tiftik keçisinin kültürel miras niteliği taşıdığını vurgulamışlardır. Buradan yola çıkılarak, bu araştırmada 1991-2019 y1lları arasındaki 28 yıllık süreçte kaydı tutularak kırkılan Ankara keçisinin ve üretilen tiftik miktarının yıllara göre değişimini, doğrusal, karesel, kübik, logaritmik ve ters regresyon modelleri ile karşılaştırmalı olarak incelenmiştir.

\section{Materyal ve Yöntem}

$\mathrm{Bu}$ çalışmanın materyalini, Türkiye İstatistik Kurumu (TÜIKK)'na ait hayvanc1lik istatistikleri verileri oluşturmaktadır (Anonim, 2020). 
Çalışmada aşağıda sırasıyla verilen matematiksel ifadelerden, basit doğrusal regresyon modeli için Eşitlik 1'deki modelden; karesel regresyon modeli ve kübik regresyon modeli için Eşitlik 2 ve Eşitlik 3 'teki modellerden; logaritmik regresyon ve ters regresyon modelleri için ise Eşitlik 4 ve 5'teki modellerden yararlanılmıştır (Rawlings ve ark., 1998; Kadılar, 2009; Chatterjee ve Hadi, 2012).

$$
\begin{aligned}
& Y=\beta_{0}+\beta_{1} X+\varepsilon \\
& Y=\beta_{0}+\beta_{1} X+\beta_{2} X^{2}+\varepsilon \\
& Y=\beta_{0}+\beta_{1} X+\beta_{2} X^{2}+\beta_{3} X^{3} \varepsilon \\
& Y=\alpha+\beta \ln x+\varepsilon \\
& Y=\alpha+\beta\left(\frac{1}{x}\right)+\varepsilon
\end{aligned}
$$

Bahsi geçen eşitliklerde $\mathrm{Y}$, bağımlı değişken ifade eder. Eşitliklerde bulunan $X, X^{2}$ ve $X^{3}$ değişkenleri ise üzerinde durulan modele ait bağımsız değişkenlerdir. $\beta_{0}$ sabit değer olup, $\beta_{1}, \beta_{2}$ ve $\beta_{3}$ ilgili modelde eğrinin biçimlendirilmesinde belirleyen parametrelerin katsayılarıdır.

Regresyon modellerinin uygulandiğ çalışmalarda bazı varsayımların sağlanması gerekir. Ünver ve ark. (2013) bu varsayımlarla ilgili olarak, normal dağılıma uygunluk, hata terimlerinin sabit varyanslı olması, hata terimleri arasında otokorelasyon (ardışık bağımlılık) sorununun olmaması gerekliliğini vurgulamışlardır.

Efe ve ark. (2000), yukarıda adı geçen tüm regresyon modellerinde (basit doğrusal, karesel, kübik, logaritmik ve ters regresyon modelleri), parametre tahminlerinde en küçük kareler yöntemi (EKK)'nin kullanıldığını bildirmişlerdir. EKK yöntemi, hata kareler toplamını en küçük yapmaya çalışan bir yöntemdir ve bu yöntemle elde edilen katsayılar "en iyi doğrusal sapmasız" tahminlerini verir.

Regresyon denklemlerinin başarısını ölçen ve denklemlerin "tahmin gücü"nü gösteren belirleme katsayısı $\left(R^{2}\right)$ ve düzeltilmiş belirleme katsayısı $\left(\operatorname{Adj}^{2}\right)$ regresyon modellerinin karşılaştırılmasında kullanılmıștır. Bununla birlikte, regresyon denklemlerinin karşılaştırılmasında hata kareler ortalamasının karekökü (Root Mean Square Error, RMSE) kriteri kullanılmıştır. Belirleme katsayısı, regresyon kareler toplamı (RKT)'nın genel kareler toplamı (GKT)'na oranıdır ve Eşitlik 6'da verildiği şekilde hesaplanmaktadır (Montgomery ve ark., 2013).

$$
R^{2}=\frac{R K T}{G K T}=\frac{\hat{\beta}^{\prime} X^{\prime} Y-\frac{\left(\sum_{i=1}^{n} Y_{i}\right)^{2}}{n}}{Y^{\prime} Y-\frac{\left(\sum_{i=1}^{n} Y_{i}\right)^{2}}{n}}
$$

Çalışmada, n gözlem ve p parametre değeri olmak üzere düzeltilmiş belirleme katsayısınınım $\left(\operatorname{Adj} R^{2}\right) \quad$ elde edilmesinde Eşitlik 7'deki matematiksel ifade kullanılmıştır (Aydın, 2014).

$$
\operatorname{Adj} R^{2}=1-\left(1-R^{2}\right) \frac{n-1}{n-p-1}
$$

Regresyon denklemlerinin karşılaştırılmasında ise RMSE' ye ilişkin matematiksel gösterimde Eşitlik 8'de verilen formül kullanılmıştır (Takma ve ark., 2012).

$$
R M S E=\sqrt{\frac{\sum_{i=1}^{n}\left(\hat{y}_{i}-y_{i}\right)^{2}}{n}}
$$

\section{Bulgular ve Tartışma}

TÜİK verilerine göre, Türkiye'de 1991-2019 yılları arasındaki Ankara keçilerinden elde edilen tiftik üretimi Şekil 1'de verilmiştir. Türkiye'de 1991 yılı itibariyle üretilen tiftik miktarı 1379 tondur. Ancak 1991 yılından itibaren, üretilen tiftik miktarında çeşitli sebeplerle sürekli bir düşüş görülmüştür. Tiftik üretiminin y1llara göre gözlenen seyri incelendiğinde, en az üretimin gerçekleştiği yıl

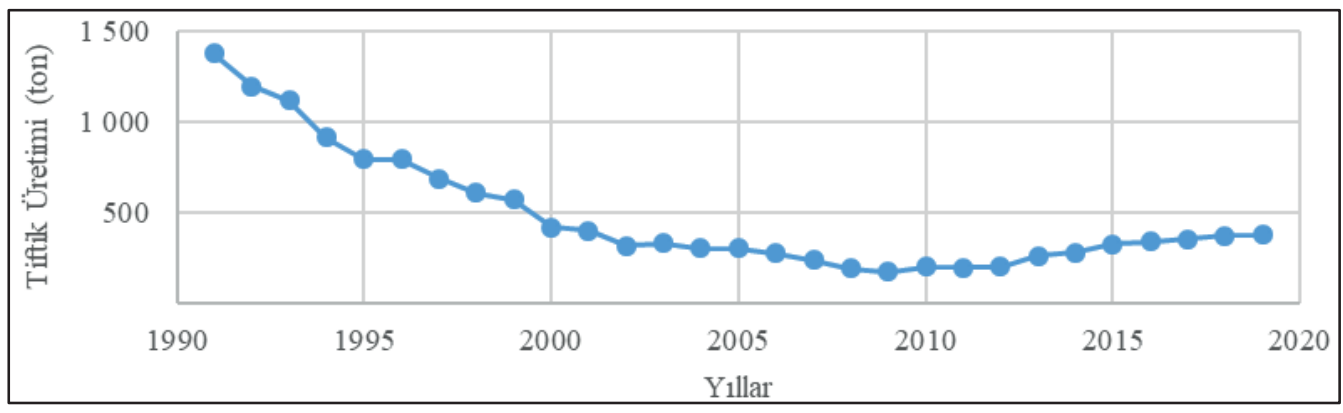

Şekil 1. Türkiye tiftik üretimi (ton) 
\% 87.38 düşüşün görüldüğü 2009 yılıdır (174 ton). TÜİK verilerine göre 2009 yılında, 99.308 baş hayvan kırkılmış olup, Ankara keçisi varlığı ise 146.986 baştır. Takip eden yıllarda, üretilen tiftik miktarında artış görülmesine rağmen, artış 2000 yılından önceki yıllarda üretilen tiftik miktarı değerine bile ulaşamamıştır. TÜİK verilerine göre 2019 y1lı verilerinde ise, kırkılan tiftik keçisi 215.208 baş, Ankara tiftik keçisi varlığı 241.055 baş, üretilen tiftik miktarı ise 380 tondur. Üretilen tiftik miktarı 2019 yılında 1991 yılına göre \% 72.48 oranında bir azalış ile 380 tona kadar düşmüştür (Şekil 1).

Çalışmada Türkiye'deki kırkılan tiftik keçisi sayısı, tiftik üretimi ve Ankara (Tiftik) keçisi varlığının 1991-2019 yılları arasındaki değişimine ilişkin analizlerde, basit doğrusal, karesel, kübik, logaritmik ve ters logaritmik regresyon modelleri karşılaştırmalı olarak incelenmiştir.

Tablo 1'de görüldüğü üzere, tüm regresyon modellerinde parametre tahminleri önemli bulunmuştur $(\mathrm{p}<0.01)$. Ancak, en düşük belirleme katsayısı $\left(R^{2}\right)$ ile düzeltilmiş regresyon katsayısı $\left(A d j R^{2}\right)$ değeri ve en yüksek RMSE değeri doğrusal regresyon ve ters regresyon denklemlerinden elde edilmiştir. Buna göre, logaritmik, karesel ve kübik regresyon denklemleri arasında karşılaştırılma yapıldığında, $R^{2}$ ve $A d j R^{2}$ değerlerinin birbirine yakın olduğu görülmüştür. En düşük RMSE kübik regresyon denkleminden elde edilmiştir. Kırkılan hayvan sayısının tahmini için kübik regresyon modelinde $R^{2}$ ve $A d j R^{2}$ değeri 0.99 ve RMSE değeri 18966.20'dir. Kullanılan modellerin mukayesesinde, belirleme katsayısı $\left(R^{2}\right)$ ile düzeltilmiş belirleme katsayısının $\left(A d j R^{2}\right)$ en yüksek olduğu ve RMSE'nin en düşük olduğu regresyon modeli en uygun model olarak belirlenmiştir (Tablo 1). Buna göre elde edilen kübik regresyon denklemi Eşitlik 9'da belirtilmiştir.

$$
Y=984442.88-102374.01 X+3699.15 X^{2}-36.60 X^{3}(9)
$$

$\mathrm{Bu}$ modele göre, 2019 yılında kırkılan tiftik keçisi sayısı (215208 baş), \% 18.17 artışla 2020 yılında 254307 baş ve \% 27.98 artışla 2021 yılında 275431 baş olacağ 1 tahmin edilmektedir.

Tablo 2'de görüldüğü üzere, tiftik üretim miktarı için uygulanan tüm regresyon modelleri, kırkılan tiftik keçisi için uygulanan regresyon modellerinde olduğu gibi parametre tahminleri önemli bulunmuştur $(\mathrm{p}<0.01)$. Benzer şekilde, en düşük $R^{2}$ ile $A d j R^{2}$ doğrusal regresyon ve ters regresyon denklemlerinde görülmüştür. Bununla birlikte yine, karesel ve kübik regresyon denklemlerinden elde edilen $R^{2}$ ve $A d j R^{2}$ değerlerinin birbirine çok yakın olduğu görülmüştür. RMSE bakımından regresyon modelleri mukayese edildiğinde, kübik regresyonun tiftik üretimi tahmininde en uygun model olduğu görülmüştür $\left(R^{2}\right.$ ve $A d j R^{2}=0.99$; RMSE= 32.64) (Tablo 2). Türkiye tiftik üretimi için uygulanan kübik regresyon denklemi Eşitlik 10'da belirtildiği gibi elde edilebilmektedir.

$$
Y=1502.99-155.50 X+5.68 X^{2}-0.06 X^{3}
$$

Kübik regresyon modeline göre Türkiye tiftik üretiminin tahmin edilen miktar1 2020 y1lında 439 ton ve 2021 y1lında ise 474 tondur. Dolayısıyla gelecek yıllarda tiftik üretiminde bir artış olabileceği beklenmektedir.

\begin{tabular}{|c|c|c|c|c|c|c|c|c|c|}
\hline \multirow{2}{*}{ Regresyon modeli } & \multicolumn{6}{|c|}{ Model özeti } & \multicolumn{3}{|c|}{ Parametre tahmini } \\
\hline & $R^{2}$ & $\operatorname{Adj} R^{2}$ & RMSE & F & $\mathrm{P}$ & Sabit $\left(\beta_{0}\right)$ & $\beta_{1}$ & $\beta_{2}$ & $\beta_{3}$ \\
\hline$\overline{\mathrm{Dog}}$ & 0.64 & 0.62 & 135288.27 & 47.56 & 0.00 & 611888.82 & $-20707.30^{* *}$ & & \\
\hline Logar & 0.90 & 0.89 & 71592.54 & 239.24 & 0.00 & 907 & $-246919.25^{* *}$ & & \\
\hline Ters & 0.74 & 0.73 & 114681.75 & 76.76 & 0.00 & 168 & $971401.69^{* *}$ & & \\
\hline Karesel & 0.99 & 0.99 & 25651.46 & 1023.96 & 0.00 & 92998 & $-82274.24^{* *}$ & $2052.23^{* *}$ & \\
\hline Kübik & 0.99 & 0.99 & 18966.20 & 1256.21 & 0.00 & 984442.88 & $-102374.01^{* *}$ & $3699.15^{* *}$ & $-36.60^{* *}$ \\
\hline
\end{tabular}

Tablo 1. Kırkılan hayvan sayısı regresyon analiz sonuçları

*: p <0.05, **: p<0.01, RMSE: Hata kareler ortalamasının karekökü, $R^{2}$ : Belirleme katsayısı, $\operatorname{Adj}^{2}$ : Düzeltilmiş belirleme katsayısı

\begin{tabular}{|c|c|c|c|c|c|c|c|c|c|}
\hline \multirow{2}{*}{ Regresyon modeli } & \multicolumn{6}{|c|}{ Model özeti } & \multicolumn{3}{|c|}{ Parametre tahmini } \\
\hline & $R^{2}$ & $\operatorname{Adj} R^{2}$ & RMSE & $\mathrm{F}$ & $P$ & Sabit $\left(\beta_{0}\right)$ & $\beta_{1}$ & $\beta_{2}$ & $\beta_{3}$ \\
\hline Doğrusal & 0.61 & 0.59 & 208.99 & 41.64 & 0.00 & 929.57 & $-29.93^{* *}$ & & \\
\hline Logaritmik & 0.88 & 0.88 & 114.32 & 202.41 & 0.00 & 1371.68 & $-362.66^{* *}$ & & \\
\hline Ters & 0.75 & 0.74 & 167.85 & 79.42 & 0.00 & 283.03 & $1446.13^{* *}$ & & \\
\hline Karesel & 0.98 & 0.98 & 41.84 & 843.46 & 0.00 & 1419.94 & $-124.84^{* *}$ & $3.16^{* *}$ & \\
\hline Kübik & 0.99 & 0.99 & 32.64 & 929.81 & 0.00 & 1502.99 & $-155.50^{* *}$ & $5.68^{* *}$ & $-0.06^{* *}$ \\
\hline
\end{tabular}

Tablo 2. Tiftik üretimi regresyon analiz sonuçları 
Tablo 3'te RMSE, $R^{2}$ ve $A d j R^{2}$ değerleri bakımından regresyon modelleri mukayese edildiğinde, kübik regresyonun tiftik üretimi tahmininde en uygun model olduğu görülmüştür $\left(R^{2}\right.$ ve $\left.A d j R^{2}=0.99 ; \mathrm{RMSE}=23410.64\right)$. Türkiye tiftik keçisi varlığına ilişkin için uygulanan kübik regresyon denklemi Eşitlik 11'de verilmiştir.

$Y=1287029.87-130898.33 X+4688.97 X^{2}-48.59 X^{3}$

Elde edilen kübik regresyon modeline göre Türkiye tiftik keçisi varlığ 2020 yılında 262123 baş ve 2021 yılında ise 263078 baştır.

Çelik ve ark. (2018a), mevcut çalışmada olduğu gibi regresyon analizi kullanarak Türkiye'de organik bal üretimdeki değişimlerini incelediği çalışmada, benzer şekilde lineer, kuadratik, kübik, logaritmik ve ters regresyon modelleri kullanmıştır. Araştırıcılar çalışmalarında, $R^{2}$ değerlerini sırasıyla $0.16,0.62,0.70,0.37,0.52 ; A d j R^{2}$ değerlerini 0.08 , $0.54,0.60,0.31,0.48$ ve hata kareler ortalamas1 (HKO) değerlerini ise 48743.01, 24376.61, 21228.61, 36580.48, 27563.47 olarak bulmuşlardır. Aynı araştırmada, düşük $R^{2}$ değerini ve en yüksek HKO değerini doğrusal modelden elde etmişlerdir. Benzer şekilde bu çalışmadan elde edilen sonuçlarda da en düşük $R^{2}$ değeri ve en yüksek RMSE (HKO'nun karekökü) değeri doğrusal modelden elde edilmiştir. Çelik ve ark. (2018a), en yüksek $R^{2}$ değeri ve en düşük HKO değeri karesel modelden elde etmişlerdir. $\mathrm{Bu}$ çalışmadan elde edilen sonuçlara göre ise en yüksek $R^{2}$ ve en düşük RMSE değeri kübik modelden elde edilmiştir. Demiraslan ve ark. (2018) ise, kıl keçileri üzerine yaptıkları çalışmada ise en uygun regresyon modelinin karesel ya da kübik model olduğunu bildirmişlerdir. Araştırmacıların elde ettikleri sonuçlar, bu çalışmanın sonuçları ile örtüşmektedir.

Türkiye'de Ankara (tiftik) keçisi varlığı 2019 yılında 241055 baştır (Anonim, 2020). Kübik regresyon modeline göre 2020 y1lında ise 268321 baş ve 2021 yılında ise 287846 baş olacağ 1 beklenmektedir. Dolayısıyla gelecek yıllarda Ankara (tiftik) keçisi varlığı bir artış olabileceği beklenmektedir. Ancak, tiftik keçisindeki artış, k1l keçisindeki artıştan çok gerilerinde kalmaktadır (Anonim, 2020).
Semerci ve Çelik (2016), geçmiş yıllar ile ilgili olarak Türkiye keçi varlığında artışının nedenini kıl keçisinden kaynaklandığını belirtmişlerdir. Araştırmacılar çalışmalarında tiftik keçisinde yaşanan gerilemede ise uygulanan politikalardan bir çözüm elde edilemediğini ve bu durumun ise oldukça endişe verici olduğunu bildirmişlerdir.

Dellal (2001), köyden kente göç ve mera alanlarındaki azalmalar, Ankara keçisi yetiştiriciliği yapmak isteyen kişi sayısındaki azalmalar, tiftik üretimindeki düşüşlerin diğer nedenleri arasında olduğunu ve bu sebepten dolayı, Türkiye gen kaynaklarından biri olan Ankara keçisinin korunması maksadıyla, yetiştiricilere yönelik, barınak, sağlık, damızlık temini gibi girdi maliyetlerini düşürecek politik atılımların atılması gerektiğini bildirmiştir.

\section{Sonuçlar}

$\mathrm{Bu}$ araştırmada, tiftik üretimi için tutulan kayıtlara göre 28 yıllık periyodda en iyi uyumun sağlanmas1 için uygulanan regresyon modellerinin belirlenmesi amaciyla RMSE değeri en düşük ve $R^{2}$ değeri en yüksek olan model tercih edilmiştir. Bu değerler dikkate alındığında, parametre tahminlerinde en uygun regresyon modelinin kübik regresyon modeli olduğuna karar verilmiştir.

Türkiye'de hayvancılık sektöründe çalışan kırsal kesimin istihdamında büyük katkısı olan tiftiğin üretiminde gelecek yıllarda çok az artış gösterme eğilimindedir. Tiftik üretiminde farklı regresyon denklemleri ile tahminler yapılsa da gelecek yıllarda yapılabilecek iyileştirmelerle elde edilebilen artış ülke ekonomisi için çok önemlidir. Tiftik üretiminin ve Ankara keçisi varlığının vahim düşüşünde, başta hayvancılık sektöründe uygulanan politikaların yetersizliği ve kamu-özel sektör iş birliğinin sağlanamayışı etkili olduğu düşünülmektedir. Bununla birlikte, tiftik kalitesinin artırılmasında, Ankara keçisinde fert başına elde edilen verimin artırılmasına yönelik hayvan sslahı çalışmalarında gerekli tedbirlerin alınmalıdır. $\mathrm{Bu}$ amaçla yapılan hayvan ıslahı çalışmalarında verilen desteklerin de uzun soluklu olması ülke ekonomisi için önemli bir durumdur.

Tablo 3. Türkiye Ankara (Tiftik) keçisi varlığına (baş) ilişkin regresyon analiz sonuçları

\begin{tabular}{|c|c|c|c|c|c|c|c|c|c|}
\hline \multirow{2}{*}{ Regresyon modeli } & \multicolumn{6}{|c|}{ Model özeti } & \multicolumn{3}{|c|}{ Parametre tahmini } \\
\hline & $R^{2}$ & $\operatorname{Adj} R^{2}$ & RMSE & $\mathrm{F}$ & $\mathrm{P}$ & Sabit $\left(\beta_{0}\right)$ & $\beta_{1}$ & $\beta_{2}$ & $\beta_{3}$ \\
\hline Doğrusal & 0.70 & 0.69 & 165264.22 & 63.10 & 0.00 & 826832.76 & $-29137.20^{* *}$ & & \\
\hline Logaritmik & 0.93 & 0.93 & 79544.79 & 361.92 & 0.00 & 1218892.48 & $-337432.09^{* *}$ & & \\
\hline Ters & 0.73 & 0.73 & 155421.63 & 74.87 & 0.00 & 212153.49 & $1300219.31^{* *}$ & & \\
\hline Karesel & 0.99 & 0.99 & 32818.49 & 1129.40 & 0.00 & 1214733.53 & $-104214.76^{* *}$ & $2502.59^{* *}$ & \\
\hline Kübik & 0.99 & 0.99 & 23410.64 & 1488.38 & 0.00 & 1287029.87 & $-130898.33^{* *}$ & $4688.97^{* *}$ & $-48.59^{* *}$ \\
\hline
\end{tabular}

*: p<0.05, **: p<0.01, RMSE: Hata kareler ortalamasının karekökü, $R^{2}$ : Belirleme katsayısı, AdjR $R^{2}$ Düzeltilmiş belirleme katsayısı 


\section{Kaynaklar}

Akbaş, Y., Taşkın, T., Demirören, E., 1999. Farklı modellerin kıvırcık ve dağlıç erkek kuzularının büyüme eğrilerine uyumunun karşılaştırılması. Turkish Journal of Veterinary and Animal Sciences, 23(3): 537-544.

Anonim, 2020. Hayvansal Üretim İstatistikleri. (https://data.tuik.gov.tr/Kategori/GetKategori?p=Tar im-111), (Erişim tarihi: 06.05.2020).

Aydın, D., 2014. Uygulamalı Regresyon Analizi/ Kavramlar ve R Hesaplamaları. Nobel Akademik Yayıncılık, Sayı: 35, Matematik-İstatistik Dizisi, Ankara.

Bağcıtek, A.K., 2017. Türkiye'de patates üretimi, sorunları, fiyat-miktar-maliyet ilişkisi. Yüksek lisans tezi, Atatürk Üniversitesi Fen Bilimleri Enstitüsü, Erzurum.

Banerjee, S., 2011. Comparative studies between some regression methods to predict carcass cuts in soviet chinchilla bucks reared in Eastern India. World Applied Sciences Journal, 14(7): 951-954.

Chatterjee, S., Hadi, A.S., 2012. Regression Analysis by Example. Fifth Edition, John Wiley and Sons, Inc., Hoboken, New Jersey.

Çelik, Ş., 2015. Türkiye'de bal üretiminin zaman serileri ile modellenmesi. Sakarya Üniversitesi Fen Bilimleri Enstitüsü Dergisi, 19(3): 377-382.

Çelik, Ş., Şengül, T., Söğüt, B., Şengül, A.Y., 2018a. A study on change of organic honey production according to years by regression analysis in turkey. Turkish Journal of Agriculture-Food Science and Technology, 6(11): 1507-1510.

Çelik, Ş., Şengül, T., İnci, H., Şengül, A.Y., 2018 b. Tüketici fiyat indeksini etkileyen bitkisel ve hayvansal üretim değerlerinin çok değişkenli uyarlanabilir regresyon uzanımları ile incelenmesi: Türkiye Örneği. Journal of Awareness, 3(Özel Sayı): 399-408.

Daşkıran, I., Cankaya, S., Darcan, N.K., Gunes, E., 2010. A case study for production system analysis of Turkish Angora goat farms. Bulgarian Journal of Agricultural Science, 16(4): 512-520.

Dellal, G., 2001. Ankara keçilerinde bazı tiftik özellikleri arasındaki fenotipik korelasyonlar. Hayvancillk Araştırma Dergisi, 11(1): 13-15.

Demiraslan, Y., Gurbuz, I., Gurkan Dilek, O., Ozudogru, S., Ozgel, O., 2018. Possibilities of estimating body weight from different body measurements in hair goat using different regression models. International Journal of Veterinary and Animal Research, 1(2): 5154.

Efe, E., Bek, Y., Şahin, M., 2000. SPSS’te Çözümleri ile
İstatistik Yöntemler II. Kahramanmaraş Sütçü İmam Üniversitesi Yayınları, Yayın No: 10, Kahramanmaraş.

Galbraith, H., 2010. Animal fibre: connecting science and production. Animal, 4(9): 1447-1450.

Gujarati, D.N., Porter, D.C., 2008. Basic Econometrics, McGraw-Hill Education; 5th Edition, Boston.

Kadılar, C., 2009. SPSS Uygulamalı Zaman Serileri Analizi. Bizim Büro Kitabevi, Ankara.

Kantürk Yiğit, G., 2011. Angora goat and Mohair production in Turkey. Archives of Applied Science Research, 3(3): 145-153.

Kaymakç1，M., 2006. Keçi Yetiştiriciliği. İzmir İli Damızlık Koyun-Keçi Yetiştiricileri Birliği Yayınları No: 2, Bornova-İzmir.

Montgomery, D.C., Elizabeth, A.P., Vining, G.G., 2013. Introduction regression analysis (doğrusal regresyon analizine giriş). Çeviren: Aydın Erar, Nobel Akademik Yayıncılık Eğitim Danışmanlık Ticaret Ltd. Şti., Ankara.

Özdemir, H., 2009. Türkiye'de Ankara keçisi yetiştiriciliğinin yapısal ve yetiştiricilik özellikleri. Doktora tezi, Ankara Üniversitesi, Fen bilimleri Enstitüsü, Ankara.

Rawlings, J.O., Pantula, S.G., Dickey, D.A., 1998. Applied Regression Analysis: A Research Tool, Second Edition, Springer-Verlag New York, USA.

Sanal, Ş., Menteş Gürler, A., Erler, M.Y., 2019. Yitirilen bir servet: Tiftik keçisi. Kafkas Üniversitesi Veteriner Fakültesi Dergisi, 25(6): 763-768.

Semerci, A., Çelik, A.D., 2016. Türkiye'de küçükbaş hayvan yetiştiriciliğinin genel durumu. Mustafa Kemal Üniversitesi Ziraat Fakültesi Dergisi, 21(2): 182-196

Tahtal1, Y., Yıldızbaş, A.T., 2020. Comparison of linear and non-linear models for definition of body features of Romanov lambs. Turkish Journal of AgricultureFood Science and Technology, 8(2): 499-503.

Takma, Ç., Atıl, H., Aksakal, V., 2012. Çoklu doğrusal regresyon ve yapay sinir ağ1 modellerinin laktasyon süt verimlerine uyum yeteneklerinin karşılaştırılması. Kafkas Üniversitesi Veteriner Fakültesi Dergisi, 18(6): 941-944.

Ünver, Ö., Gamgam, H., Altunkaynak, B., 2013. SPSS Uygulamalı Temel İstatistik Yöntemler. Seçkin Yayıncılik, Ankara.

Zimmermann, M.J., Kuehn, L.A., Spangler, M.L., Thallman, R.M., Warren, M., Snelling, W.M., Lewis, M.L., 2019. Comparison of different functions to describe growth from weaning to maturity in crossbred beef cattle. Journal of Animal Science, 97(4): 1523-1533. 